Review

\title{
Antidepressant Treatment of Depression in the Elderly: Efficacy and Safety Considerations
}

Trevor R Norman *

Department of Psychiatry, University of Melbourne, Austin Hospital, Heidelberg 3084, Victoria, Australia; E-Mail: trevorrn@unimelb.edu.au

* Correspondence: Trevor R Norman; E-Mail: trevorrn@unimelb.edu.au

Academic Editor: Ray Marks

Special Issue: Depression and Aging

OBM Neurobiology

2021, volume 5 , issue 4

doi:10.21926/obm.neurobiol.2104108
Received: February 07, 2021

Accepted: October 03, 2021

Published: October 14, 2021

\begin{abstract}
Depression in the elderly is a significant clinical problem which is likely to endure as an ongoing issue as the cohort of individuals aged over 65years continues to increase as a proportion of the total population. While there are a multiplicity of approaches to the treatment of depression, the mainstay for moderate to severe cases is pharmacotherapy. The majority of extant antidepressants have demonstrated efficacy, at least in short term (6-12weeks) clinical evaluations. There is demonstrable efficacy over and above that of placebo in the majority of clinical trials for most agents. Within the classes of antidepressants there is no difference between individual agents, while between classes differences have not been demonstrated consistently. Thus, there appears to be little to choose between the various agents. However, considerations other than efficacy play a role in the choice of an antidepressant for an individual patient. A systematic review of the efficacy of antidepressant agents based on trials in elderly populations is presented. Factors influencing the choice of a medication over and above efficacy are presented along with a brief review of adverse events of particular concern in elderly patients. A considerable proportion of elderly patients have comorbid medical conditions, which may also influence the choice of agent due to drug-drug interaction considerations. A brief overview of interactions likely to influence medication selection is also
\end{abstract}

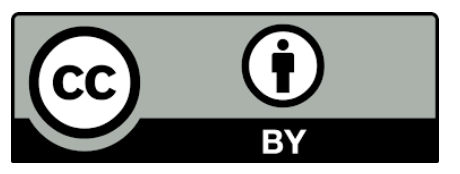
conditions of the Creative Commons by Attribution License, which permits unrestricted use, distribution, and reproduction in any medium or format, provided the original work is correctly cited. 
canvassed. While there is every reason to be optimistic about outcomes in elderly patients, there are still unanswered questions about antidepressant efficacy in this population: effectiveness in long-term treatment and in the population of so-called 'old-old' elderly are principal among them.

\section{Keywords}

Depression; elderly; pharmacotherapy; antidepressants; side effects; drug-drug interactions

\section{Introduction}

Major depression in older individuals may be experienced as a new condition, so-called late onset depression, or in those who have already experienced an episode earlier in life (early onset depression) [1]. Various studies suggest that more than half of depressive episodes in older patients are of the 'late onset' type. In a group of geriatric patients (aged 65 to 102 years) receiving home care $13.5 \%$ were diagnosed with major depression and of these patients $71 \%$ were experiencing a first episode of depression [2]. There may be biological features, particularly structural brain alterations and vascular changes, which are aetiologically important risk factors associated with late onset depression [3]. Despite these findings both structural and vascular changes are likely to be important for both early and late onset major depression [4].

In epidemiological studies of community-dwelling elderly populations clinically significant depressive symptoms are present in up to $15 \%$ of respondents [5] whereas a much smaller subsample, perhaps 1-5\%, meet the criteria for major depression [6]. Prevalence of depression in nursing homes has been estimated at $25 \%$ in one study [7]. Clearly prevalence estimates are influenced by the survey setting [8]. The presence of physical disorders, such as cardiovascular disease and chronic pain complaints, may conflate the estimates [5].

Irrespective of the prevalence of the disorder, major depression in older subjects is associated with significant morbidity and mortality. The presentation of depression in the elderly is often different from that in younger subjects. Thus, while many younger patients report symptoms such as dysphoria and guilt / worthlessness these may not be ratified by older patients [1]. Common presenting complaints in older patients include anxiety, somatic symptoms, and memory loss. In the latter case the differential diagnosis of dementia needs to be excluded. Suicide and attempted suicide are high in the elderly, particularly elderly men, with divorced, never married or widowers identified as particular risk factors [8]. Treatment response and remission rates in the elderly are often lower [9].

\section{Pharmacological Treatment of Depression}

In cases of moderate to severe depression the mainstay of treatment for older adults is the same as that for younger adults namely, pharmacotherapy. All classes of antidepressants have been investigated for their efficacy in older patients although the evidence base is often limited. For example, the so-called "third generation or multimodal" antidepressants are not as well evaluated in specific elderly populations as tricyclic and Selective Serotonin Reuptake Inhibitor (SSRI) antidepressants. For the group of patients described as the 'old-old', nominally encompassing 
patients greater than 85 years of age, there is significantly less evidence, based on controlled clinical evaluations, of the efficacy of most antidepressant medications [10]. Given an increased life expectancy in the majority of developed and developing countries this group constitutes an ever increasing proportion of a population. The growing number of individuals in this age bracket would suggest an increased need for mental health treatments, assuming the prevalence of disorders remains similar to current estimates. Similarly, patients with known high rates of depression such as those who reside in nursing homes, who have dementia and medical comorbidities are also generally excluded from clinical trials resulting in a lack of clinical evidence guiding treatment [10].

Most reviews of clinical data suggest that all classes of antidepressants are equally effective in the treatment of depression in the elderly [8] but that certain socio-demographic features of the illness may also influence outcome [11]. Male gender and Caucasian ethnicity were identified as influencing poorer overall outcomes [11]. Furthermore, clinical features of illness such as duration of the present episode, number of previous episodes, low baseline severity of illness and age $>65$ years were also associated with poorer outcomes [11]. The later finding agrees with a metaanalysis of placebo controlled trials, which found that older age (>65years) was generally associated with poorer clinical outcomes [12]. A recent meta-analysis of 44 studies of patients aged 65 years or above receiving short-term (4-12 weeks) treatment with antidepressants concluded that $~ 50 \%$ patients could expect to achieve a response to medication (defined as a $50 \%$ reduction in baseline score of depression) [13].

\subsection{Tricyclic Antidepressants}

Among the oldest antidepressants in clinical use there is a substantial body of evidence for the efficacy of tricyclic antidepressants (TCAs) in treating depression in the elderly. A comprehensive tabulation of clinical studies in specific elderly populations is available elsewhere [14]. A systematic review examined the acute efficacy of antidepressants versus placebo in patients aged 55 years and older [15]. Of the 18 trials reviewed, 12 examined the efficacy of tricyclics and concluded that both imipramine and nortriptyline were superior to placebo over the 4-8 week treatment period. None of the studies reported remission rates, the standard for assessing outcomes in antidepressant trials [16]. Comparative agents were included in some trials with no difference in efficacy demonstrated between the tricyclic and other antidepressants. These conclusions were supported by a later metaanalysis which found tricyclics superior to placebo based on response to treatment ( $\geq 50 \%$ decrease in baseline depression rating score or a Clinical Global Impression score of 1 or 2 at endpoint) [17]. On the other hand, only three trials reported remission rates and failed to establish a significant difference between drug and placebo on this measure. This result is perhaps not surprising given the short durations (6-8 weeks) of treatment and the longer times to response in most older patients [18]. Among tricyclic antidepressants no one medication has established superiority over another [14]. Choices between different agents are most likely to be made according to the most common side effect profiles of individual agents i.e., which side effects are undesirable in a particular patient due to their comorbid medical conditions. It is claimed that secondary amine tricyclics (e.g., nortriptyline, desipramine) are preferred to tertiary amine types (e.g., imipramine, amitriptyline) as these have milder side effects and a less complex metabolic profile [14]. Nortriptyline is the most extensively studied of the tricyclic antidepressants but like other tricyclics, anticholinergic side effects are prominent and there are issues related to cardiovascular toxicity, especially on overdose [19]. 
Despite the evidence that tricyclic antidepressants are effective in the treatment of late life depression the CANMAT guidelines do not recommend them as first line treatment [20]. Nortriptyline is recommended as a second line treatment while amitriptyline and imipramine are regarded as third line options. On the other hand, some guidelines do not recommend the use of tricyclic antidepressants in elderly patients at all [21]. Specific reasons cited for the recommendation include high anticholinergic activity, sedative effects and orthostatic hypotension. Only low dose doxepin $(<6 \mathrm{mg} /$ day) was not included in these categories. Doxepin at doses of $3-6 \mathrm{mg} /$ day is occasionally used for night sedation [22].

\subsection{Monoamine Oxidase Inhibitors}

Few controlled trials examining the efficacy of monoamine oxidase inhibitors (MAOIs) have been performed in specific elderly populations. Studies involving MAOls in elderly populations are summarised in Table 1. An early study compared phenelzine to nortriptyline and placebo using double-blind methodology in patients with depression treated over 7 weeks [23]. A total of 75 patients aged 55-76years entered the study and were randomly assigned to one of the treatment arms. Statistically significant differences between nortriptyline and placebo were evident from week 2 of treatment and from week 3 for phenelzine compared to placebo. There was no difference between the two active medications. Response rates at week 7, defined as a Hamilton Depression Rating Scale (HAM-D) score $\leq 10$, were $13 \%$ for placebo and $\sim 61 \%$ for both active drugs. The mean dose of nortriptyline was $79 \mathrm{mg} /$ day and of phenelzine $54 \mathrm{mg} /$ day. Side effects were reported more often for medicated patients than for placebo with anticholinergic effects more frequent in nortriptyline treated patients, while orthostatic effects were equally present in both phenelzine and nortriptyline treated patients. 
Table 1 Efficacy of monoamine oxidase inhibitors in late life depression.

\begin{tabular}{|c|c|c|c|c|c|c|}
\hline $\begin{array}{l}\text { Drug and } \\
\text { Dosages* }\end{array}$ & Drug & Sample & Age & Design of Study & Outcomes & Reference \\
\hline \multicolumn{7}{|l|}{ Brofaromine } \\
\hline Brofaromine & & 127 & $68 \pm 6$ & Randomised, double-blind, 8 & HAM-D $26.3 \pm 7.7$ to $12.2 \pm 9.2$ & {$[24]$} \\
\hline (86mg/day) & & 62 & $68 \pm 6$ & weeks with open label follow-up & $26.0 \pm 7.8$ to $12.6 \pm 9.0$ & \\
\hline $\begin{array}{l}\text { Imipramine } \\
\text { (88mg/day) }\end{array}$ & & & & & Baseline to week 8; Brofaromine=Imipramine & \\
\hline \multicolumn{7}{|l|}{ Phenelzine } \\
\hline Phenelzine & & 22 & $56-72$ & Randomised, double blind, & HAM-D ${ }^{\S}: 22.1$ to 9.6 & {$[23]$} \\
\hline (53.9mg/day) & & 25 & $55-76$ & placebo controlled, 7 weeks & 22.6 to 10.1 & \\
\hline Nortriptyline & & 28 & $55-75$ & & 23.1 to 20.3 & \\
\hline (79mg/day) & & & & & Baseline to week 7; Phenelzine=Nortriptyline $>$ Placebo & \\
\hline \multicolumn{7}{|l|}{ Placebo } \\
\hline \multicolumn{7}{|l|}{ Moclobemide } \\
\hline Moclobemide & $(150-$ & 13 & $69.9 \pm$ & Double-blind, sequential paired & HAM-D: $25.8 \pm 5.8$ to $15.0 \pm 8.7$ & {$[25]$} \\
\hline 600mg/day) & & 13 & 5.4 & trial & $25.2 \pm 4.6$ to $16.8 \pm 9.1$ & \\
\hline $\begin{array}{l}\text { Mianserin } \\
\text { 90mg/day) }\end{array}$ & $(30-$ & & $\begin{array}{l}69.6 \pm \\
6.4\end{array}$ & & Baseline to week 4; Moclobemide=Mianserin & \\
\hline $\begin{array}{l}\text { Moclobemide } \\
500 \mathrm{mg} / \text { day) }\end{array}$ & $(300-$ & $80^{* *}$ & $60-80$ & $\begin{array}{l}\text { Randomised, double-blind, } 4 \\
\text { weeks }\end{array}$ & $\begin{array}{l}\text { HAM-D: } 23.4 \text { to } 11.1 \\
22.5 \text { to } 10.0\end{array}$ & {$[26]$} \\
\hline $\begin{array}{l}\text { Mianserin } \\
125 \mathrm{mg} / \text { day) }\end{array}$ & $(75-$ & & & & Baseline to week 4; Moclobemide=Mianserin & \\
\hline $\begin{array}{l}\text { Moclobemide } \\
300 \mathrm{mg} / \text { day) }\end{array}$ & $(150-$ & $39 * *$ & $>60$ & $\begin{array}{l}\text { Randomised, double-blind, } 6 \\
\text { weeks }\end{array}$ & $\begin{array}{l}\text { HAM-D: } 33.4 \pm 5.8 \text { to } 5.1 \pm 5.3 \\
29.4 \pm 3.5 \text { to } 5.1 \pm 6.8\end{array}$ & {$[26]$} \\
\hline $\begin{array}{l}\text { Maprotiline } \\
\text { 150mg/day) }\end{array}$ & $(75-$ & & & & Baseline week 6; Moclobemide=Maprotiline & \\
\hline
\end{tabular}




\begin{tabular}{|c|c|c|c|c|c|c|c|}
\hline Moclobemide & 36 & $60-90$ & Randomised, & double-blind, & 7 & Remission rates (HAM-D<10): Moclobemide 23\% & {$[27]$} \\
\hline (400mg/day) & 38 & $62-88$ & weeks & & & Nortriptyline 33\% & \\
\hline Nortriptyline & 35 & $62-89$ & & & & Placebo $11 \%$ & \\
\hline (75mg/day) & & & & & & At week 7 of treatment & \\
\hline \multicolumn{8}{|l|}{ Placebo } \\
\hline $\begin{array}{l}\text { Moclobemide } \\
\text { (400mg/day) }\end{array}$ & $\begin{array}{l}368 \\
358\end{array}$ & $60-90$ & $\begin{array}{l}\text { Randomised, } \\
\text { weeks }\end{array}$ & double-blind, & 6 & $\begin{array}{l}\text { Mean Change in HAM-D from Baseline after } 6 \text { weeks } \\
\text { treatment: Moclobemide } 12.1\end{array}$ & {$[28]$} \\
\hline Placebo & & & & & & Placebo 8.1; Moclobemide> Placebo; P=0.001 & \\
\hline
\end{tabular}

* Average doses throughout the study

**Number of patients per group not stated

$\S$ HAM-D score adjusted for baseline as a covariate in the statistical analysis. HAM-D: Hamilton Depression Rating Scale 
Phenelzine represents an example of older MAOIs which are classified as irreversible, nonselective inhibitors of monoamine oxidase type $A$ and $B$. Later developments introduced agents which are reversible inhibitors and selective for type A monoamine oxidase referred to as RIMAs. Two such agents have been investigated in the elderly: moclobemide and brofaromine. Brofaromine was demonstrated to be equivalent to imipramine in an 8-week double-blind comparative trial in 189 elderly depressed patients based on the HAM-D scale [24]. Brofaromine maintained its efficacy in patients treated for up to 12-months. A more extensive database is available for the use of moclobemide in elderly patients. Moclobemide was superior to placebo in two controlled trials [27, 28]. In a 4-week comparative study moclobemide 300-500mg was equivalent to mianserin 75 $125 \mathrm{mg}$ [26]. This finding was supported by an 8-week comparison which showed that moclobemide $600 \mathrm{mg}$ and mianserin $90 \mathrm{mg}$ produced equal responses on HAM-D scores [25]. Similarly, treatment with moclobemide (150-300 mg/day) or maprotiline (75-150 mg/day) for 6 weeks were equally effective for elderly depressed patients [26].

While comparative and open-label studies suggest that MAOIs are efficacious and are equally effective as other antidepressants for geriatric depression, they are less likely to be used due to side effects, particularly postural hypotension. The necessity for strict dietary restrictions with MAOI use has been questioned due to the generally lower tyramine content of modern day foods [29]. It would seem prudent however to continue to issue warnings about the potential for a tyramine pressor response.

\subsection{Selective Serotonin Reuptake Inhibitors}

Selective serotonin reuptake inhibitors (SSRIS) are regarded as the treatments of choice for first line management of elderly depressed patients [30-34]. Placebo controlled trials have established that all of the currently available SSRIs (fluoxetine, paroxetine, sertraline, fluvoxamine, escitalopram and citalopram) are effective in achieving a clinical response in the short term, although there is a relatively limited database $[35,36]$. The number needed to treat to achieve a response was estimated at 10 whereas the ability to achieve remission, at least in the short term, was not different from placebo in a meta-analysis [17].

Comparative studies of SSRI versus other classes of antidepressants have also been conducted. The comparative efficacy of the single action SSRIs was compared to that of dual action antidepressants such as Serotonin and Noradrenaline Reuptake Inhibitors (SNRIs) and TCAs [37]. Contrary to expectations that dual acting medications would be superior to the single mode of action agents, no additional benefits were conferred by the use of the dual agents. A later comparison of SSRIs and TCAs also concluded that there was no significant difference between the two classes when the criterion of remission was used [17]. This same review suggested no significant difference with other classes of antidepressants when evaluating head-to-head comparisons, albeit with a limited database.

According to one review sertraline, citalopram or escitalopram are preferred SSRIs in the elderly due to their lower drug-drug interaction profile, notwithstanding the issues of an increased risk of GI bleeding when taken with Non-Steroidal Anti-inflammatory (NSAIDs) drugs and prolonged prothrombin time with warfarin [38]. Furthermore, SSRIs are recommended treatments in depressed patients with a history of cardiovascular disease [39]. QTc prolongation, a surrogate risk marker for Torsades de Pointe, has been associated with the use of citalopram and escitalopram, the effect being dose dependent [40]. This finding prompted warning of the use of these drugs in 
patients with hepatic impairment, $>60$ years of age, in CYP2C19 poor metabolisers, or receiving concomitant CYP2C19 inhibitors [41].

\subsection{Dual Reuptake Inhibitors}

While the SSRIs are the more likely choice of treatment in late-life depression, there remain many patients who do not benefit significantly from these agents. So-called dual reuptake inhibitors or serotonin-noradrenaline reuptake inhibitors (SNRIS) represent an alternative and have been evaluated for use in elderly populations. Table 2 summarises some clinical evaluations in older aged patients. Both venlafaxine and duloxetine have a more extensive suite of studies although some of the studies to date are not placebo controlled and there is equivocal agreement concerning the efficacy of these medications. Two other SNRIS, desvenlafaxine and milnacipran, have a limited data base. Thus, desvenlafaxine reduced depressive symptoms in an open evaluation after six-months of treatment [42]. Pooled analysis of studies examining desvenlafaxine versus placebo have generally failed to find any differences in responses to medication between distinct age cohorts, including those aged 65years or more $[43,44]$. Doses used in these studies were $50-100 \mathrm{mg} /$ day. Milnacipran was shown to be as effective as imipramine in one study (Table 2 ) with response rates of about $60 \%$ after 8-weeks of treatment [45]. Neither milnacipran nor desvenlafaxine could be recommended as first line treatments due to the paucity of data attesting their efficacy in late-life depression. 
Table 2 Efficacy of Dual Reuptake Inhibitors in Late-Life Depression.

\begin{tabular}{|c|c|c|c|c|c|}
\hline $\begin{array}{l}\text { Drug and Drug } \\
\text { Dosages* }\end{array}$ & Sample & Age & $\begin{array}{l}\text { Design of } \\
\text { Study }\end{array}$ & Outcome & Reference \\
\hline \multicolumn{6}{|l|}{ DESVENLAFAXINE } \\
\hline $\begin{array}{l}\text { Desvenlafaxine } 100 \text { - } \\
200 \mathrm{mg}\end{array}$ & 52 & $65-87$ & Open label & HAM-D: $21.7 \pm 3.2$ to $8.3 \pm 5.7$; Baseline to 24 weeks & {$[42]$} \\
\hline \multicolumn{6}{|l|}{ VENLAFAXINE } \\
\hline Venlafaxine 225- & 34 & $71 \pm 5.4$ & Randomised, & Efficacy based on remission rates (HAM-D $\leq 7$ ) at & {$[46]$} \\
\hline 300mg & 34 & $70 \pm 3.9$ & single-blind & 24weeks: & \\
\hline $\begin{array}{l}\text { Nortriptyline } 50- \\
100 \mathrm{mg}\end{array}$ & & & & Venlafaxine $(71 \%)=$ nortriptyline $(70 \%)$ & \\
\hline Venlafaxine 18.75- & 27 & $81.2 \pm$ & Randomised, & HAM-D: $20.3 \pm 3.7$ to $15.7 \pm 6.2$ & {$[47]$} \\
\hline 150mg & 25 & 10.8 & double-blind & $20.2 \pm 3.4$ to $12.2 \pm 5.1$ & \\
\hline Sertraline $25-100 \mathrm{mg}$ & & $\begin{array}{l}83.8 \pm \\
9.8\end{array}$ & & Baseline to week 10; venlafaxine=sertraline & \\
\hline Venlafaxine 37.5- & 73 & $73.6 \pm$ & Randomised, & MADRS: $27.6 \pm 3.6$ to $12.0 \pm 7.7$ & [48] \\
\hline 150mg & 75 & 5.972 .5 & double-blind & $27.0 \pm 3.6$ to $11.5 \pm 9.6$ & \\
\hline Citalopram 10-30mg & & \pm 5.7 & & Baseline to week 8; Venlafaxine = citalopram & \\
\hline Venlafaxine $37.5-$ & 104 & 71 & Randomised, & Efficacy based on remission rates (HAM-D $\leq 7)$ at 8 & [49] \\
\hline $225 \mathrm{mg}$ & 100 & 71 & double-blind & weeks: & \\
\hline Fluoxetine $20-60 \mathrm{mg}$ & 96 & 71 & & Venlafaxine $(27 \%)=$ fluoxetine $(20 \%)=$ placebo $(24 \%)$ & \\
\hline Placebo & & & & & \\
\hline Venlafaxine $75-375 \mathrm{mg}$ & 40 & $71.6 \pm$ & Randomised, & Efficacy based on remission rates (MADRS $\leq 10$ ) at 12 & {$[50]$} \\
\hline Nortriptyline $25-$ & 41 & 6.872 .8 & double-blind & weeks: & \\
\hline 200mg & & \pm 8.4 & & Venlafaxine $(27.5 \%)=$ nortriptyline $(36.6 \%)$ & \\
\hline Venlafaxine $37.5-$ & 14 & $77.6 \pm$ & Randomised, & MADRS: $21.8 \pm 9.0$ to $11.4 \pm 8.2$ & {$[51]$} \\
\hline $131.25 \mathrm{mg}$ & 17 & 7.377 .6 & double-blind & $19.2 \pm 6.1$ to $12.2 \pm 8.7$ & \\
\hline Placebo & & \pm 5.8 & & Baseline to week 6; venlafaxine=placebo & \\
\hline
\end{tabular}




\begin{tabular}{|c|c|c|c|c|c|}
\hline $\begin{array}{l}\text { Venlafaxine } 75-300 \mathrm{mg} \\
\text { Paroxetine } 10-60 \mathrm{mg}\end{array}$ & $\begin{array}{l}15 \\
15\end{array}$ & $\begin{array}{l}68-81 \\
70-83\end{array}$ & $\begin{array}{l}\text { Randomised, } \\
\text { single-blind }\end{array}$ & $\begin{array}{l}\text { Efficacy based on remission rates (HAM-D } \leq 7) \text { at } 6 \\
\text { weeks: } \\
\text { Venlafaxine }(60 \%)>\text { paroxetine }(33 \%)\end{array}$ & {$[52]$} \\
\hline \multicolumn{6}{|l|}{ DULOXETINE } \\
\hline Duloxetine $80-120 \mathrm{mg}$ & 101 & $65-87$ & Open label & $\begin{array}{l}\text { Efficacy based on remission rates (HAM-D } \leq 7) \text { at } 6,28 \text {, } \\
52 \text { weeks: } 41.4 \%, 69.8 \%, 72.3 \%\end{array}$ & {$[53]$} \\
\hline $\begin{array}{l}\text { Duloxetine 40-120mg } \\
\text { Placebo }\end{array}$ & $\begin{array}{l}47 \\
43\end{array}$ & $\begin{array}{l}55-75 \\
55-82\end{array}$ & $\begin{array}{l}\text { Randomised, } \\
\text { double-blind }\end{array}$ & $\begin{array}{l}\text { Efficacy based on remission rates }(\mathrm{HAM}-\mathrm{D} \leq 7) \text { at } 9 \\
\text { weeks: Duloxetine }(30.4 \%)>\text { placebo }(14.3 \%)\end{array}$ & {$[54]^{\S \S}$} \\
\hline $\begin{array}{l}\text { Duloxetine } 60 \mathrm{mg} \\
\text { Placebo }\end{array}$ & $\begin{array}{l}207 \\
104\end{array}$ & $\begin{array}{l}72.6 \pm \\
5.7 \\
73.3 \pm \\
5.7\end{array}$ & $\begin{array}{l}\text { Randomised, } \\
\text { double-blind }\end{array}$ & $\begin{array}{l}\text { Efficacy based on remission rates }(\mathrm{HAM}-\mathrm{D} \leq 7) \text { at } 8 \\
\text { weeks: Duloxetine }(27.4 \%)>\text { placebo }(14.7 \%)\end{array}$ & {$[55]$} \\
\hline Duloxetine $30-120 \mathrm{mg}$ & 40 & $\begin{array}{l}74.4 \pm \\
7.0\end{array}$ & Open label & $\begin{array}{l}\text { Rescue medication from non-response to } \\
\text { escitalopram; } 50 \% \text { met criteria for a response; median } \\
\text { time to response } 12 \text { weeks }\end{array}$ & {$[56]$} \\
\hline $\begin{array}{l}\text { Duloxetine } 60-120 \mathrm{mg} \\
\text { Placebo }\end{array}$ & $\begin{array}{l}204 \\
95\end{array}$ & $\begin{array}{l}73.0 \pm \\
6.3 \\
73.1 \pm \\
5.6\end{array}$ & $\begin{array}{l}\text { Randomised, } \\
\text { double-blind }\end{array}$ & $\begin{array}{l}\text { Maier subscale HAM-D: Change from baseline to } \\
\text { week } 12 \text { : duloxetine }(-4.34 \pm 0.29) \text {; placebo }(-3.90 \pm \\
0.44) \text { not significant; duloxetine > placebo other time } \\
\text { points }\end{array}$ & {$[57]$} \\
\hline Duloxetine $30-120 \mathrm{mg}$ & 35 & $65-87$ & Open label & $\begin{array}{l}\text { HAM-D: } 21.00 \pm 5.32 \text { to } 14.95 \pm 4.67 \text { significant } \\
\text { reduction in score from baseline to week } 52\end{array}$ & {$[58]$} \\
\hline \multicolumn{6}{|l|}{ MILNACIPRAN } \\
\hline $\begin{array}{l}\text { Milnacipran } 100 \mathrm{mg} \\
\text { Imipramine } 100 \mathrm{mg}\end{array}$ & 219 & $65-93$ & $\begin{array}{l}\text { Randomised, } \\
\text { double-blind }\end{array}$ & $\begin{array}{l}\text { HAM-D: } 25.8 \pm 4.5 \text { to } \sim 10^{\text {व }} \\
25.1 \pm 4.7 \text { to } \sim 10 \\
\text { Milnacipran = imipramine day } 56 ; 59.8 \% \text { responders } \\
\text { both groups }\end{array}$ & {$[45]$} \\
\hline
\end{tabular}

$\S \S$ Data for this study were derived from a pooled analysis of two randomised, double-blind trials utilising only data for patients $>65 y$ years \. Raw data not reported; extrapolated from reported figure

HAM-D: Hamilton Depression Rating Scale; MADRS: Montgomery-Asberg Depression Rating Scale. 
Venlafaxine has an extensive set of studies evaluating its efficacy in older patients and which provide somewhat contradictory outcomes. In a single blind trial venlafaxine was as effective as the tricyclic antidepressant nortriptyline in alleviating the symptoms of depression (Table2), with similarly high remission rates in both groups [46]. On the other hand, a study employing a doubleblind methodology over 12 weeks of treatment showed somewhat better remission rates for nortriptyline treated patients [50]. Although the difference between drugs was not statistically significant, the remission rates were decidedly smaller in the later study (Table 2). Head to head comparisons with SSRIs have shown venlafaxine to be equivalent in clinical responses (either remission rates or changes in depression rating scores) as sertraline [47] and citalopram [48]. In one study it was found to be superior in efficacy to paroxetine [52] but this study was conducted in relatively few subjects and was single-blind so perhaps subject to bias. Furthermore, in a doubleblind, placebo-controlled, parallel group study venlafaxine did not separate from either fluoxetine or placebo based on remission rates [49]. In a smaller randomised double-blind study venlafaxine also failed to separate from placebo based on changes in depression rating scores over a 6-week period [51]. These negative results may relate to the modest doses of venlafaxine employed, the relatively short treatment time frames (6-8weeks), which may be insufficient for recovery to occur or to high drop-out rates due to side effects of the medications, thereby biasing statistical analysis.

Duloxetine has been evaluated in three double-blind, placebo controlled short-term evaluations of 9-12 weeks duration (Table 2). In two of the studies duloxetine was superior to placebo when the primary outcome was remission rates $[54,55]$. Rate of remission for duloxetine in both studies was $\sim 30 \%$ compared to $\sim 15 \%$ for placebo. The relatively low remission rates might be explained by the duration of treatment as late-life depression seems to require longer response and remission times (vide supra). In the third study, also double-blind and of 12 weeks duration, duloxetine did separate from placebo [57]. In this study the primary outcome measure was the Maier subscale ${ }^{1}$ of the Hamilton Depression rating scale and was not significantly different at week 12 of the study. At other assessment weeks duloxetine was favoured over placebo by the primary outcome measure while secondary outcome measures favoured drug over placebo at all time points. This would suggest that duloxetine is effective in the treatment of depression. Three open evaluations suggested an antidepressant effect of duloxetine. In one study there was an increasing rate of remission of symptoms over a 52-week study period [53]. A small evaluation also reported a statistically significant reduction in depression scores over a 52-week treatment period [58]. These studies represent a scare few available attesting to the efficacy of antidepressants in late-life depression in the long term. The final open evaluation examined the efficacy of duloxetine in patients who had failed to respond to a course of treatment with citalopram [56]. Within a median time of 12 -weeks $\sim 50 \%$ of citalopram non responders were converted to duloxetine responders.

The body of evidence accrued would suggest that SNRI antidepressants are effective in the treatment of late-life depression and offer an alternative pharmacotherapy option when other medications have failed. While there is less accumulated clinical trial evidence than is the case for other drugs and fewer head to head comparisons there is little reason to believe that SNRIs are not as effective as other antidepressants. It is unlikely however, that these agents would be seen as a first line treatment due to a relatively high side effect burden.

\footnotetext{
${ }^{1}$ The Maier subscale utilises six items from the HAM-D full scale which focus on the core symptoms of depression. See Maier W., Philipp M. Improving the assessment of severity of depressive states: a reduction of the Hamilton Depression Scale. Pharmacopsychiatry. 1985;18:114-115.
} 


\subsection{Other Agents}

A number of other antidepressant agents have been evaluated in specific elderly populations and include some recently developed medications, agomelatine and vortioxetine, as well as the older agent mirtazapine.

\subsubsection{Mirtazapine}

The use of mirtazapine in depressed nursing home residents was investigated in 119 subjects aged 70 years or more [59]. Patients received mirtazapine $15-45 \mathrm{mg} /$ day for 12 weeks and response was evaluated using the Hamilton scale for depression. At end-point $47 \%$ of patients were classified as responders on the Hamilton scale ( $54 \%$ on the CGI scale), while there was a statistically significant decline from baseline to end-point on the depression scale. The drug was described as well tolerated. A post-hoc evaluation of the data set showed that advanced age, medical illness, and cognitive impairment were not a priori predictors of response [60]. In an analysis of data from patients $>85$ years the drug was also effective in reducing overall depression scores [61]. Mirtazapine (15-45mg/day) was compared to amitriptyline (30-90mg/day) in 115 patients aged 60 to 85 years in a randomised, double-blind trial over 6 weeks [62]. There was no statistically significant difference between treatments based on depression rating scales (HAM-D, Montgomery Asberg Depression Rating Scale (MADRS)) at the end of treatment. Comparison of mirtazapine (15-45mg/day) and paroxetine (20-40mg/day) was performed in 246 patients aged $>65$ years in a randomised, doubleblind trial over 8 weeks [63]. Both drugs significantly reduced the HAM-D scores from baseline, but a statistically superior effect was noted for mirtazapine from day 7 . The median time to achieve a response ( $50 \%$ reduction HAM-D score) was 26 days for mirtazapine and 40 days for paroxetine. On the other hand, the proportion of responders at end point based on the CGI score was not different (64\% v 57\% for mirtazapine and paroxetine respectively). An advantage of mirtazapine, particularly for elderly patients who may have difficulty swallowing, is the availability of an oral disintegrating tablet formulation.

\subsubsection{Agomelatine}

Agomelatine combines actions as a melatonin agonist and a serotonin antagonist with both actions regarded as essential for its clinical antidepressant effects [64]. Some open evaluations in small populations have suggested a good therapeutic effect in elderly populations. In these studies, 6-12 weeks treatment with agomelatine $25-50 \mathrm{mg} /$ day was reported to lead to a significant reduction in depressive symptoms [65-68]. A double blind placebo controlled trial did not support the efficacy of agomelatine however, this trial lacked assay sensitivity due to a high placebo response rate [69]. Nevertheless, a controlled trial over 8 weeks showed response rates of 59.5\% and $38.6 \%$ for agomelatine and placebo, respectively, although remission rates were not significantly different [70]. Further clinical trials are necessary to evaluate the place of agomelatine in the treatment of elderly depressed patients but the effects of agomelatine on sleep may be particularly beneficial. 


\subsubsection{Vortioxetine}

Vortioxetine is regarded as a multimodal antidepressant with actions as a 5-HT3 and 5-HT7 receptor antagonist, 5-HT1B receptor partial agonist, 5-HT1A receptor agonist as well as an inhibitor of the serotonin (5-HT) transporter [71]. An 8-week double-blind study compared vortioxetine (5 $\mathrm{mg} /$ day) with duloxetine (60mg/day) and placebo in 453 elderly patients (mean age 71years) [72]. Both active drugs were superior to placebo in reducing depression scores with response (HAM-D $\geq 50 \%$ decrease from baseline) achieved by $53.2 \%, 63.3 \%$ and $35.2 \%$ of vortioxetine, duloxetine and placebo patients respectively. Remission rates (HAM-D<7) were $29.2 \%, 34.7 \%$ and $19.3 \%$ for vortioxetine, duloxetine and placebo, respectively. A post-hoc analysis of data from 12 short-term (6-8weeks) fixed dose, placebo controlled trials examined the response to vortioxetine in 1508 elderly patients aged 55-88years [73]. Based on the change from baseline in depression rating scores all doses of vortioxetine included in the studies: 5,10 and $20 \mathrm{mg} /$ day were superior to placebo. Response rates were superior to placebo for 10 and $20 \mathrm{mg}$ and remission rates for $20 \mathrm{mg}$. The analysis concluded that vortioxetine was an effective antidepressant for elderly patients. A double-blind placebo controlled study examined the efficacy of vortioxetine $(15 \mathrm{mg} /$ day) versus sertraline ( $75 \mathrm{mg} /$ day) in 50 elderly patients (>60 years) over 6 -weeks [74]. There was no significant difference in the change in depression scores from baseline between the two drugs. Response rate $(100 \% \mathrm{v}$ $44 \%$; vortioxetine and sertraline respectively) and remission rate ( $24 \%$ v $40 \%)$ were not statistically significantly different between treatments. Vortioxetine has demonstrated improvements on cognitive function tests in depression which may be an advantage for this agent in an elderly cohort [75].

\section{Pharmacotherapy Side Effects of Concern in the Elderly}

All antidepressants are associated with well-known side effects / adverse events which are particular to the different classes. For example, tricyclic antidepressants are associated with a range of anticholinergic effects (dry mouth, blurred vision, constipation, urinary hesitancy) experienced by most patients who take them, to varying degrees of severity. In the majority of cases these effects occur at the initiation of treatment or when doses are increased with tolerance developing following continued administration. The SSRIs are more likely to be associated with agitation, nausea, diarrhoea, constipation, headache and insomnia. While these effects are clearly inconvenient for patients and often contribute to lack of compliance with medication, they do not often lead to serious medical events. On the other hand, there are several actions of antidepressants which are of concern in patients receiving antidepressants and in elderly patients in particular. While there are few absolute contraindications to the use of antidepressants in the elderly there are some effects which give cause for consideration. For example, a TCA would be avoided in a patient with a history of myocardial infarction or cardiac conduction defects or a male with benign prostatic hypertrophy. The propensity of SSRIs to increase bleeding events might give pause to their use in a patient receiving anticoagulants. A series of important adverse events associated with the different classes of antidepressants is outlined in Table 3. The table is not exhaustive, but the events listed are judged to be of importance in elderly populations in particular. The table assumes that patients are receiving monotherapy, which for the majority of elderly patients is not the case and opens the possibility of interactions between antidepressants and medications prescribed for comorbid conditions. Other events not presented in Table 3 concern sexual dysfunction and osteoporosis. All 
antidepressants are associated with sexual dysfunction in both men (for review see [76]) and women (for review see [77]). The effect of antidepressants on bone mineral density is somewhat controversial with some maintaining little or no effect above an increased risk associated with depression itself [78]. On the other hand, a systematic review suggested that SSRIs were associated with decreased bone mineral density and TCAs increased the risk of fractures [79]. A further consideration applies to both young and elderly patients using antidepressants, namely withdrawal syndromes on cessation of treatment. Most antidepressants are implicated but there are differences between medications, even within the same class of agent, as to the tendency to cause a withdrawal effect [80]. The syndrome most frequently manifests as flu-like symptoms, but other symptoms may be observed. For this reason, a tapered withdrawal on discontinuation of treatment is recommended, if not to alleviate withdrawal symptoms completely, then at least to attenuate the severity. 
Table 3 Antidepressant side effects of importance in elderly patients.

\begin{tabular}{|c|c|c|c|c|c|c|c|}
\hline $\begin{array}{l}\text { Antidepressant } \\
\text { Class }\end{array}$ & $\begin{array}{l}\text { Cardiovascular } \\
\text { Effects }\end{array}$ & $\begin{array}{l}\text { Bleeding } \\
\text { Events* }\end{array}$ & Hyponatremia ${ }^{\S}$ & Hypotension & Sedation & Weight Effects & $\begin{array}{l}\text { Anticholinergic } \\
\text { Effects }\end{array}$ \\
\hline Tricyclics & $\begin{array}{lr}\text { All } & \text { drugs } \\
\text { increase } & \text { QRS } \\
\text { width } & \text { on } \\
\text { overdose; may } \\
\text { lead } \\
\text { arrhythmias and } \\
\text { death }\end{array}$ & $\begin{array}{l}\text { Low risk when } \\
\text { taken alone; } \\
\text { note } \\
\text { interactions } \\
\text { with warfarin }\end{array}$ & $\begin{array}{lr}\text { Low risk } \\
\text { compared } \\
\text { SSRIs, SNRIs }\end{array}$ & $\begin{array}{l}\text { Moderate to } \\
\text { strong effects } \\
\text { with most: } \\
\text { dependent on } \\
\alpha_{1} \text {-adrenergic } \\
\text { binding } \\
\text { potency }\end{array}$ & $\begin{array}{l}\text { More potent } \\
\text { effects with } \\
\text { tertiary amine } \\
\text { types }\end{array}$ & $\begin{array}{l}\text { All drugs may } \\
\text { cause a gain in } \\
\text { weight }\end{array}$ & $\begin{array}{l}\text { Strong effects } \\
\text { with tertiary } \\
\text { amines; mild to } \\
\text { moderate } \\
\text { effects with } \\
\text { secondary } \\
\text { amine types }\end{array}$ \\
\hline MAOIs & $\begin{array}{l}\text { Tachycardia; } \\
\text { hypertensive } \\
\text { crisis with } \\
\text { tyramine foods; } \\
\text { QTc } \\
\text { prolongation } \\
\text { with } \\
\text { moclobemide }\end{array}$ & $\begin{array}{l}\text { Low risk when } \\
\text { taken alone }\end{array}$ & $\begin{array}{l}\text { Risk is unclear } \\
\text { but probably } \\
\text { lower than } \\
\text { TCAs }\end{array}$ & $\begin{array}{l}\text { May develop } \\
\text { with ongoing } \\
\text { use: 6-weeks } \\
\text { to months }\end{array}$ & $\begin{array}{l}\text { Not usually } \\
\text { sedative more } \\
\text { likely to be } \\
\text { activating }\end{array}$ & $\begin{array}{l}\text { Weight gain } \\
\text { associated } \\
\text { with non- } \\
\text { selective } \\
\text { inhibitors }\end{array}$ & Low risk \\
\hline SSRIS & $\begin{array}{l}\text { Mild at } \\
\text { therapeutic } \\
\text { doses; } \\
\text { bradycardia, } \\
\text { conduction } \\
\text { abnormalities; } \\
\text { overdoses; QT } \\
\text { prolongation for } \\
\text { citalopram, } \\
\text { escitalopram }\end{array}$ & $\begin{array}{l}\text { Increased risk } \\
\text { of upper GI } \\
\text { bleeding with } \\
\text { as little as } 7 \\
\text { days use }\end{array}$ & $\begin{array}{l}\text { Higher risk than } \\
\text { younger } \\
\text { patients; } \\
\text { increased risk if } \\
\text { combined with } \\
\text { thiazides; } \\
\text { paroxetine, } \\
\text { sertraline lower } \\
\text { risk? }\end{array}$ & $\begin{array}{l}\text { Low risk of } \\
\text { effects; } \\
\text { increased risk } \\
\text { of falls }\end{array}$ & $\begin{array}{l}\text { Paroxetine, } \\
\text { fluvoxamine } \\
\text { may cause } \\
\text { effects; not } \\
\text { usual with } \\
\text { others }\end{array}$ & $\begin{array}{l}\text { Mostly weight } \\
\text { neutral; long } \\
\text { term use may } \\
\text { have } \\
\text { associated } \\
\text { weight gain }\end{array}$ & $\begin{array}{l}\text { Dry mouth with } \\
\text { paroxetine in } \\
\text { some patients }\end{array}$ \\
\hline
\end{tabular}




\begin{tabular}{|c|c|c|c|c|c|c|c|}
\hline SNRIS & $\begin{array}{l}\text { Elevation of BP; } \\
\text { QTc } \\
\text { prolongation in } \\
\text { overdose for } \\
\text { venlafaxine }\end{array}$ & $\begin{array}{l}\text { Low risk of } \mathrm{Gl} \\
\text { bleeding }\end{array}$ & $\begin{array}{l}\text { All drugs } \\
\text { implicated; } \\
\text { higher risk for } \\
\text { duloxetine? }\end{array}$ & $\begin{array}{l}\text { Dose } \\
\text { dependent } \\
\text { effects on BP: } \\
\text { hypotension at } \\
\text { low dose } \\
\text { increased BP } \\
\text { with increasing } \\
\text { doses }\end{array}$ & $\begin{array}{l}\text { Low risk of } \\
\text { excessive } \\
\text { sedation }\end{array}$ & $\begin{array}{l}\text { Less likely to } \\
\text { cause weight } \\
\text { gain }\end{array}$ & Few effects \\
\hline Others & & $\begin{array}{l}\text { Low risk for } \\
\text { mirtazapine }\end{array}$ & $\begin{array}{l}\text { Low risk for } \\
\text { mirtazapine }\end{array}$ & $\begin{array}{l}\text { Mirtazapine at } \\
\text { therapeutic } \\
\text { and overdoses }\end{array}$ & $\begin{array}{l}\text { Mirtazapine } \\
\text { highly sedative }\end{array}$ & $\begin{array}{l}\text { Mirtazapine } \\
\text { prone to large } \\
\text { weight gains; } \\
\text { agomelatine } \\
\text { weight neutral }\end{array}$ & $\begin{array}{l}\text { Mirtazapine, } \\
\text { agomelatine } \\
\text { very low } \\
\text { incidence }\end{array}$ \\
\hline
\end{tabular}

* Based on Wang YP, Chen YT, Tsai CF, Li SY, Luo JC, Wang SJ, Tang CH, Liu CJ, Lin HC, Lee FY, Chang FY, Lu CL. Short-term use of serotonin reuptake inhibitors and risk of upper gastrointestinal bleeding. Am J Psychiatry. 2014; 171: 54-61.

$\S$ Based on data from De Picker L, Van Den Eede F, Dumont G, Moorkens G, Sabbe BG. Antidepressants and the risk of hyponatremia: a class-by-class review of literature. Psychosomatics. 2014; 55: 536-547. 


\section{Drug-drug Interactions}

Old age is often a time of declining health and a myriad of medications are used to treat the conditions of this phase of life. Adding antidepressant medications to existing regimens inevitably raises the potential for drug-drug interactions which may occur as a result of pharmacokinetic or pharmacodynamic changes [81]. The majority of medications, including antidepressants, are extensively metabolised in the liver utilising enzymes of the cytochrome P450 system. Some antidepressants act as inhibitors others as inducers of individual cytochrome enzymes. This conjunction of effects may result in the alteration of the pharmacokinetics of one or more of the agents administered. For example, the effectiveness of codeine is reduced by co-administration with paroxetine, an inhibitor of CYP2D6. However, the clinical consequences for an individual may be difficult to predict. A detailed account of antidepressant drug-drug interactions in elderly patients is reviewed elsewhere [82]. Pharmacodynamic interactions occur when one drug interferes with the effects of another through a physiological mechanism by competition at a receptor site (e.g., effectiveness of older antihypertensive agents reduced by TCAs); augmentation of the same neurotransmitter pathway (e.g., SSRI and tramadol leading to serotonin syndrome); effects on the functioning of an organ / organ system (e.g., SSRIs impair clotting and NSAIDs irritate the gastric mucosa leading to increased risk of bleeding when taken together). The latter two interactions are worthy of close attention in the elderly.

\section{Conclusions}

Late-life depression is generally considered as a recurring disorder [4] whereas most evaluations of the efficacy of antidepressants are short-term trials. Few studies have evaluated the robustness of the antidepressant response in elderly depressed patients over longer time frames. Studies that have evaluated antidepressants for longer follow-ups generally support the continuing efficacy of antidepressants, particularly if they are combined with some form of psychotherapy. The combination of nortriptyline and interpersonal psychotherapy (IPT) was superior to IPT and placebo and showed a trend to superior efficacy over nortriptyline monotherapy when assessing recurrence rates over three years [83]. A similar response was noted in initial responders to paroxetine followed up over a two year period: the combination of paroxetine and IPT prevented relapse and outperformed either paroxetine or IPT alone [84].

The aims of treatment of late life depression include to reduce symptoms of the disorder, prevent relapse and suicide and to improve psychosocial functioning [4]. To this end antidepressant medications have a role to play but other non-pharmacological approaches are also as important. Medications need to be used judiciously and may not be appropriate for every case of depression. In mild depressions psychotherapy may be as useful as medications, without the attendant side effects [85]. For moderate to severe depression antidepressants are likely to be necessary. Although all agents appear to be equally effective in treating late-life depression the SSRI and SNRI agents are preferred [4]. Newer agents such as agomelatine and vortioxetine may also prove to be first line choices due to effects on sleep and cognition respectively. At this time there is too little data to strongly recommend their use as first line. TCAs, nortriptyline or desipramine may be preferred in severe cases [4]. 
Further research is necessary to establish practical guidelines for the treatment of late-life depression. More extensive evaluation of the efficacy of newer agents in the specific elderly populations, including the "old-old", are also necessary.

\section{Author Contributions}

The author did all the research work of this study.

\section{Competing Interests}

The author has declared that no competing interests exist.

\section{References}

1. Fiske A, Wetherell JL, Gatz M. Depression in older adults. Ann Rev Clin Psychol. 2009; 5: 363-389.

2. Bruce ML, McAvay GJ, Raue PJ, BrownEL, Meyers BS, Keohane DJ, et al. Major depression in elderly home health care patients. Am J Psychiatry. 2002; 159: 1367-1374.

3. Hickie I, Scott E, Naismith S, Ward PB, Turner K, Parker G, et al. Late-onset depression: Genetic, vascular and clinical contributions. Psychol Med. 2001; 31: 1403-1412.

4. Alexopoulos GS. Depression in the elderly. Lancet. 2005; 365: 1961-1970.

5. Blazer DG. Depression in late life: Review and commentary. J Gerontol A. 2003; 58: M249-M265.

6. Hasin DS, Goodwin RD, Stinson FS, Grant BF. Epidemiology of major depressive disorder: Results from the national epidemiologic survey on alcoholism and related conditions. Arch Gen Psychiatry. 2005; 62: 1097-1106.

7. Samuels SC, Katz IB. Depression in the nursing home. Psychiatr Ann. 1995; 25: 419-424

8. Mock P, Norman TR, Olver JS. Contemporary therapies for depression in older people. J Pharm Pract Res. 2010; 40: 58-64.

9. Driscoll HC, Karp JF, Dew MA, Reynolds CF. Getting better, getting well: Understanding and managing partial and non-response to pharmacological treatment of non-psychotic major depression in old age. Drugs Aging. 2007; 24: 801-814.

10. Giron MS, Fastbom J, Winblad B. Clinical trials of potential antidepressants: To what extent are the elderly represented: A review. Int J Geriatr Psychiatry. 2005; 20: 201-217.

11. Calati R, Signorelli MS, Balestri M, Marsano A, De Ronchi D, Aguglia E, et al. Antidepressants in elderly: Meta-regression of double-blind, randomized clinical trials. J Affect Dis. 2013; 147: 1-8.

12. Tedeschini E, Levkovitz Y, lovieno N, Ameral VE, Nelson JC, Papakostas Gl. Efficacy of antidepressants for late-life depression: A meta-analysis and meta-regression of placebocontrolled randomized trials. J Clin Psychiatry. 2011; 72: 1660-1668.

13. Gutsmiedl K, Krause M, Bighelli I, Schneider-Thoma J, Leucht S. How well do elderly patients with major depressive disorder respond to antidepressants: A systematic review and single-group metaanalysis. BMC Psychiatry. 2020; 20: 1-12. 
14. Alexopoulos GS, Lerner DM, Salzman C. Treatment of depression with tricyclic antidepressants, monoamine oxidase inhibitors and psychostimulants. In: Clinical geriatric psychopharmacology. Philadelphia: Lippincott, Williams and Wilkins; 2005. p. 233-303.

15. Taylor WD, Doraiswamy PM. A systematic review of antidepressant placebo-controlled trials for geriatric depression: Limitations of current data and directions for the future. Neuropsychopharmacol. 2004; 29: 2285-2299.

16. Keller MB. Past, present, and future directions for defining optimal treatment outcome in depression: Remission and beyond. JAMA. 2003; 289: 3152-3160.

17. Kok RM, Nolen WM, Heeren TJ. Efficacy of treatment in older depressed patients: A systematic review and meta-analysis of double-blind randomized controlled trials with antidepressants. J Affect Dis. 2012; 141: 103-115.

18. Birrer RB, Vemuri SP. Depression in later life: A diagnostic and therapeutic challenge. Am Fam Physician. 2004; 69: 2375-2382.

19. Pruckner N, Holthoff-Detto V. Antidepressant pharmacotherapy in old-age depression-a review and clinical approach. Eur J Clin Pharmacol. 2017; 73: 661-667.

20. MacQueen GM, Frey BN, Ismail Z, Jaworska N, Steiner M, Van Lieshout RJ, et al. Canadian Network for Mood and Anxiety Treatments (CANMAT) 2016 clinical guidelines for the management of adults with major depressive disorder: Section 6. Special populations: Youth, women, and the elderly. Can J Psychiat. 2016; 61: 588-603.

21. American Geriatrics Society 2019 updated AGS Beers Criteria ${ }^{\circledR}$ for potentially inappropriate medication use in older adults. J Am Geriatr Soc. 2019; 67: 674-694.

22. Abad VC, Guilleminault C. Insomnia in elderly patients: Recommendations for pharmacological management. Drugs Aging. 2018; 35: 791-817.

23. Georgotas A, McCue RE, Hapworth W, Friedman E, Kim OM, Welkowitz J, et al. Comparative efficacy and safety of MAOls versus TCAs in treating depression in the elderly. Biol Psychiatry. 1986; 21: 1155-1166.

24. Moller HJ, Volz HP. Brofaromine in elderly major depressed patients- a comparative trial versus imipramine. Eur Neuropsychopharm. 1993; 3: 501-510.

25. Nair NP, Amin M, Holm P, Katona C, Klitgaard C, Ng Ying Kin NM, et al. Moclobemide and nortriptyline in elderly depressed patients: A randomized, multicentre trial against placebo. J Affect Disord. 1995; 33: 1-9.

26. Roth $M$, Mountjoy CQ, Amrien R. Moclobemide in elderly patients with cognitive decline and depression: An international double-blind, placebo-controlled trial. Br J Psychiatry. 1996; 168: 149157.

27. De Vanna M, Kummer J, Agnoli A, Gentili P, Lorizio A, Anand R. Moclobemide compared with second-generation antidepressants in elderly people. Acta Psychatr Scand. 1990; 82: 64-66.

28. Tiller J, Maguire K, Davies B. A sequential double-blind controlled study of moclobemide and mianserin in elderly depressed patients. Int J Geriatric Psychiat. 1990; 5: 199-204.

29. Gillman PK. A reassessment of the safety profile of monoamine oxidase inhibitors: Elucidating tired old tyramine myths. J Neural Transm. 2018; 125: 1707-1717. 
30. Mulsant BH, Alexopoulos GS, Reynolds CF, Katz IR, Abrams R, Oslin D. Pharmacological treatment of depression in older primary care patients: The PROSPECT algorithm. Int J Geriatr Psychiatry. 2001; 16: 585-592.

31. Roose SP, Schatzberg AF. The efficacy of antidepressants in the treatment of late-life depression. J Clin Psychopharmacol. 2005; 25: S1-S7.

32. Rajji TK, Mulsant BH, Lotrich FE, Lokker C, Reynolds CF. Use of antidepressants in late-life depression. Drugs Aging. 2008; 25: 841-853.

33. Casey DA. Depression in the elderly: A review and update. Asia-Pacific Psychiatry. 2012; 4: 160-167.

34. Norman TR. Pharmacotherapy for mood and anxiety disorders. In: Mental Health and IIness of the Elderly. Singapore: Springer; 2017.

35. Nelson JC, Delucchi K, Schneider LS. Efficacy of second generation antidepressants in late-life depression: A meta-analysis of the evidence. Am J Geriatr Psychiatry. 2008; 16: 558-567.

36. Topiwala A, Chouliaras L, Ebmeier KP. Prescribing selective serotonin reuptake inhibitors in older age. Maturitas. 2014; 77: 118-123.

37. Mukai Y, Tampi RR. Treatment of depression in the elderly: A review of the recent literature on the efficacy of single- versus dual-action antidepressants. Clin Therap. 2009; 31: 945-961.

38. Chemali Z, Chahine LM, Fricchione G. The use of selective serotonin reuptake inhibitors in elderly patients. Harv Rev Psychiatry. 2009; 17: 242-253.

39. Alamo C, Lopez-Munoz F, Garcia-Garcia P, Garcia-Ramos S. Risk-benefit analysis of antidepressant drug treatment in the elderly. Psychogeriatrics. 2014; 14: 261-268.

40. Beach SR, Celano CM, Sugrue AM, Adams C, Ackerman MJ, Noseworthy PA, et al. QT prolongation, torsades de pointes, and psychotropic medications: A 5-year update. Psychosomatics. 2018; 59 : 105-122.

41. FDA drug safety communication: Revised recommendations for Celexa (citalopram hydrobromide) related to a potential risk of abnormal heart rhythms with high doses [Internet]. Silver Spring, Maryland: U.S. Food and Drug Administration; 2017. Available from: http://www.fda.gov/drugs/drugsafety/ucm297391.htm.

42. Ferguson J, Tourian KA, Manley AL, Padmanabhan SK, Nichols A. An evaluation of the efficacy, safety, and tolerability of desvenlafaxine in the long-term treatment of elderly outpatients with major depressive disorder. Prim Psychiatry. 2010; 17: 66-73.

43. Kornstein SG, Clayton AH, Soares CN, Padmanabhan SK, Guico-Pabia CJ. Analysis by age and sex of efficacy data from placebo-controlled trials of desvenlafaxine in outpatients with major depressive disorder. J Clin Psychopharmacol. 2010; 30: 294-299.

44. Mosca D, Zhang M, Prieto R, Boucher M. Efficacy of desvenlafaxine compared with placebo in major depressive disorder patients by age group and severity of depression at baseline. J Clin Psychopharmacol. 2017; 37: 182-192.

45. Tignol J, Pujol-Domenech J, Chartres JP, Léger JM, Plétan Y, Tonelli I, et al. Double-blind study of the efficacy and safety of milnacipran and imipramine in elderly patients with major depressive episode. Acta Psychiatr Scand. 1998; 97: 157-165.

46. Gastó C, Navarro V, Marcos T, Portella MJ, Torra M, Rodamilans M. Single-blind comparison of venlafaxine and nortriptyline in elderly major depression. J Clin Psychopharmacol. 2003; 23: 21-26. 
47. Kok RM, Nolen WA, Heeren TJ. Venlafaxine versus nortriptyline in the treatment of elderly depressed inpatients: A randomised, double-blind, controlled trial. Int J Geriatr Psychiatry. 2007; 22: 1247-1254.

48. Oslin DW, Have TR, Streim JE, Datto CJ, Weintraub D, DiFilippo S, et al. Probing the safety of medications in the frail elderly: Evidence from a randomized clinical trial of sertraline and venlafaxine in depressed nursing home residents. J Clin Psychiatry. 2003; 64: 875-882.

49. Allard P, Gram L, Timdahl K, Behnke K, Hanson M, Søgaard J. Efficacy and tolerability of venlafaxine in geriatric outpatients with major depression: A double-blind, randomised 6-month comparative trial with citalopram. Int J Geriatr Psychiatry. 2004; 19: 1123-1130.

50. Mazeh D, Shahal B, Aviv A, Zemishlani H, Barak Y. A randomized, single-blind, comparison of venlafaxine with paroxetine in elderly patients suffering from resistant depression. Int Clin Psychopharmacol. 2007; 22: 371-375.

51. Schatzberg A, Roose S. A double-blind, placebo-controlled study of venlafaxine and fluoxetine in geriatric outpatients with major depression. Am J Geriatr Psychiatry. 2006; 14: 361-370.

52. de Vasconcelos Cunha UG, Lopes Rocha F, Avila de Melo R, Alves Valle E, de Souza Neto JJ, Mendes Brega $R$, et al. A placebo-controlled double-blind randomized study of venlafaxine in the treatment of depression in dementia. Dement Geriatr Cogn Disord. 2007; 24: 36-41.

53. Nelson JC, Wohlreich MM, Mallinckrodt CH, Detke MJ, Watkin JG, Kennedy JS. Duloxetine for the treatment of major depressive disorder in older patients. Am J Geriatr Psychiatry. 2005; 13: $227-$ 235.

54. Raskin J, Wiltse CG, Siegal A, Sheikh J, Xu J, Dinkel JJ, et al. Efficacy of duloxetine on cognition, depression, and pain in elderly patients with major depressive disorder: An 8-week, double-blind, placebo-controlled trial. Am J Psychiatry. 2007; 164: 900-909.

55. Robinson M, Oakes TM, Raskin J, Liu P, Shoemaker S, Nelson JC. Acute and long-term treatment of late-life major depressive disorder: Duloxetine versus placebo. Am J Geriatr Psychiatry. 2014; 22 : 34-45.

56. Wohlreich MM, Mallinckrodt CH, Watkin JG, Hay DP. Duloxetine for the long-term treatment of major depressive disorder in patients aged 65 and older: An open-label study. BMC Geriatr. 2004; 4: 1-10.

57. Rovera C, Mauri MC, Bertin E, Di Pace C, Paletta S, Reggiori A, et al. Duloxetine in elderly major depression disorder: Effectiveness and drug plasma level evaluation. Hum Psychopharmacol Clin Exp. 2016; 31: 349-355.

58. Karp JF, Whyte EM, Lenze EJ, Dew MA, Begley A, Miller MD, et al. Rescue pharmacotherapy with duloxetine for selective serotonin reuptake inhibitor non-responders in late-life depression: Outcome and tolerability. J Clin Psychiatry. 2008; 69: 457-463.

59. Roose SP, Nelson JC, Salzman C, Hollander SB, Rodrigues H. Open-label study of mirtazapine orally disintegrating tablets in depressed patients in the nursing home. Curr Med Res Opin. 2003; 19: 737746.

60. Nelson JC, Hollander SB, Betzel J, Smolen P. Mirtazapine orally disintegrating tablets in depressed nursing home residents 85 years of age and older. Int J Geriatr Psychiatry. 2006; 21: 898-901. 
61. Nelson JC, Holden K, Roose S, Salzman C, Hollander SB, Betzel JV. Are there predictors of outcome in depressed elderly nursing home residents during treatment with mirtazapine orally disintegrating tablets? Int J Geriat Psychiat. 2007; 22: 999-1003.

62. Høyberg OJ, Maragakis B, Mullin J, Norum D, Stordall E, Ekdahl P, et al. A double-blind multicentre comparison of mirtazapine and amitriptyline in elderly depressed patients. Acta Psychiatr Scand. 1996; 93: 184-190.

63. Schatzberg AF, Kremer C, Rodrigues HE, Murphy Jr GM, Mirtazapine vs. Paroxetine Study Group. Double-blind, randomized comparison of mirtazapine and paroxetine in elderly depressed patients. Am J Geriatr Psychiatry. 2002; 10: 541-550.

64. Norman TR, Olver JS. Agomelatine for depression: Expanding the horizons. Expert Opin Pharmacother. 2019; 20: 647-656.

65. Laux G, VIVALDI Study Group. The antidepressant agomelatine in daily practice: Results of the noninterventional study VIVALDI. Pharmacopsychiatry. 2012; 45: 284-291.

66. Lužný J. Agomelatine in elderly--finally a patient friendly antidepressant in psychogeriatry? Actas Esp Psiquiatr. 2012; 40: 304-307.

67. Gavrilova SI, Kolykhalov IV, Ponomareva EV, Selezneva ND. Clinical experience with agomelatine for the treatment of depression in elderly patients in outpatient practice. Zh Nevrol Psikhiatr Im S S Korsakova. 2014; 114: 43-48.

68. Kalyn YB, Safarova TP, Yakovleva OB, Sheshenin VS, Kornilov VV, Shipilova ES, et al. Experience of the antidepressive therapy with valdoxan (agomelatine) in a psychogeriatric unit of the psychiatric hospital. Zh Nevrol Psikhiatr Im S S Korsakova. 2015; 115: 55-62.

69. Goodwin GM, Thomas P, Heun R, Boyer P, Picarel-Blanchot F, de Bodinat C. Antidepressant effect in older depressed patients: The lessons of two agomelatine trials. Int Clin Psychopharmacol. 2017; 32: 184-194.

70. Heun R, Ahokas A, Boyer P, Giménez-Montesinos N, Pontes-Soares F, Olivier V. The efficacy of agomelatine in elderly patients with recurrent major depressive disorder: A placebo-controlled study. J Clin Psychiatry. 2013; 74: 587-594.

71. Sanchez C, Asin KE, Artigas F. Vortioxetine, a novel antidepressant with multimodal activity: Review of preclinical and clinical data. Pharmacol Ther. 2015; 145: 43-57.

72. Katona C, Hansen T, Olsen CK. A randomized, double-blind, placebo-controlled, duloxetinereferenced, fixed-dose study comparing the efficacy and safety of Lu AA21004 in elderly patients with major depressive disorder. Int Clin Psychopharmacol. 2012; 27: 215-223.

73. Nomikos GG, Tomori D, Zhong W, Affinito J, Palo W. Efficacy, safety, and tolerability of vortioxetine for the treatment of major depressive disorder in patients aged 55 years or older. CNS Spectr. 2017; 22: 348-362.

74. Borhannejad F, Shariati B, Naderi S, Shalbafan M, Mortezaei A, Sahebolzamani E, et al. Comparison of vortioxetine and sertraline for treatment of major depressive disorder in elderly patients: $\mathrm{A}$ double-blind randomized trial. J Clin Pharm Ther. 2020; 45: 804-811.

75. Frampton JE. Vortioxetine: A review in cognitive dysfunction in depression. Drugs. 2016; 76: 16751682. 
76. Segraves RT, Balon R. Antidepressant-induced sexual dysfunction in men. Pharmacol Biochem Behav. 2014; 121: 132-137.

77. Lorenz T, Rullo J, Faubion S. Antidepressant-induced female sexual dysfunction. Mayo Clin Proc. 2016; 91: 1280-1286.

78. Gebara MA, Shea ML, Lipsey KL, Teitelbaum SL, Civitelli R, Müller DJ, et al. Depression, antidepressants, and bone health in older adults: A systematic review. J Am Geriatr Soc. 2014; 62: 1434-1441.

79. Rizzoli R, Cooper C, Reginster JY, Abrahamsen B, Adachi JD, Brandi ML, et al. Antidepressant medications and osteoporosis. Bone. 2012; 51: 606-613.

80. Olver JS, Burrows GD, Norman TR. Discontinuation syndromes with Selective Serotonin Reuptake Inhibitors: Are there clinically relevant differences? CNS Drugs. 1999; 12: 171-177.

81. Spina E, Scordo MG. Clinically significant drug interactions with antidepressants in the elderly. Drugs Aging. 2002; 19: 299-320.

82. Schellander R, Donnerer J. Antidepressants: Clinically relevant drug interactions to be considered. Pharmacology. 2010; 86: 203-215.

83. Reynolds III CF, Frank E, Perel JM, Imber SD, Cornes C, Miller MD, et al. Nortriptyline and interpersonal psychotherapy as maintenance therapies for recurrent major depression: $A$ randomized controlled trial in patients older than 59 years. JAMA. 1999; 281: 39-45.

84. Reynolds III CF, Dew MA, Pollock BG, Mulsant BH, Frank E, Miller MD, et al. Maintenance treatment of major depression in old age. N Engl J Med. 2006; 354: 1130-1138.

85. Kok RM, Reynolds III CF. Management of depression in older adults: A review. JAMA. 2017; 317: 2114-2122.

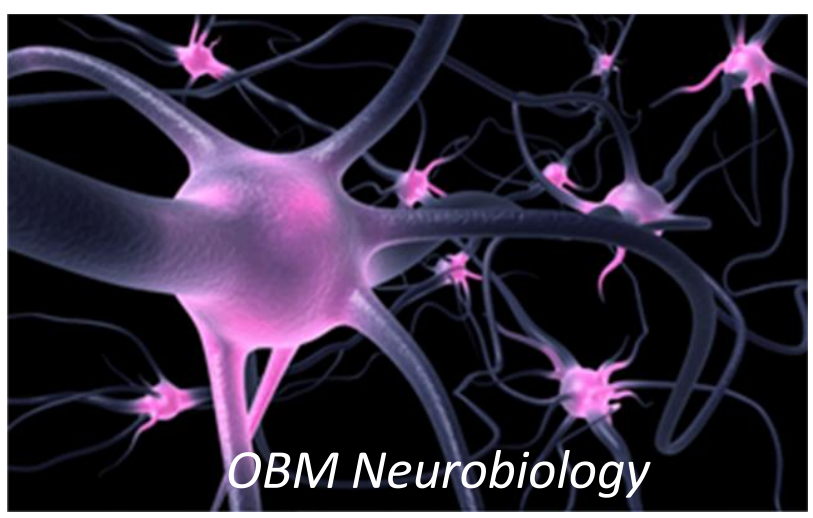

Enjoy OBM Neurobiology by:

1. Submitting a manuscript

2. Joining volunteer reviewer bank

3. Joining Editorial Board

4. Guest editing a special issue

For more details, please visit:

http://www.lidsen.com/journals/neurobiology 